\section{RSP}

http://www.rsp.fsp.usp.br/
Revista de Saúde Pública

\title{
Public policies on healthcare-associated infections: a Brazil and UK case study
}

\author{
Maria Clara Padoveze', Sara Melo", Simon Bishop"I', Vanessa de Brito Poveda", Carlos Magno \\ Castelo Branco Fortalezav \\ ' Universidade de São Paulo. Escola de Enfermagem. Departamento de Enfermagem em Saúde Coletiva. São \\ Paulo, SP, Brasil \\ " Queen's University Belfast. Queen's Management School. Belfast, Northern Ireland, United Kingdom \\ II' University of Nottingham. Nottingham University Business School. Nottingham, United Kingdom \\ iv Universidade de São Paulo. Escola de Enfermagem. Departamento de Enfermagem Médico Cirúrgica. São \\ Paulo, SP, Brasil \\ $\checkmark$ Universidade Estadual Paulista. Faculdade de Medicina de Botucatu. Departamento de Doenças Tropicais. \\ Botucatu, SP, Brasil
}

\begin{abstract}
To summarize the historical events and drivers underlying public policy for the prevention and control of healthcare-associated infections in Brazil and in the United Kingdom. In doing so, the article aims to identify lessons and recommendations for future development of public policy. The analysis is based on a historical overview of national healthcare-associated infections programs taken from previously published sources. Findings highlight how the development of healthcare-associated infections prevention and control policies followed similar trajectories in Brazil and the United Kingdom. This can be conceptualized around four sequential phases: Formation, Consolidation, Standardization, and Monitoring and Evaluation. However, while we identified similar phases of development in Brazil and the United Kingdom, it can be seen that the former entered each stage around 20 years after the latter.
\end{abstract}

DESCRIPTORS: Cross Infection, prevention \& control. Infection Control, organization \& administration Public Health Policy. Public Health, history.

Correspondence:

Maria Clara Padoveze

Departamento de Enfermagem em

Saúde Coletiva

Escola de Enfermagem - USP

Av. Dr. Enéas de Carvalho Aguiar, 419

054003-000 São Paulo, SP, Brasil

Received: Oct 17, 2016

Approved: Apr 2, 2017

How to cite: Padoveze MC, Melo S, Bishop S, Poveda VB, Fortaleza CMCB. Public policies on healthcare-associated infections: a Brazil and UK case study. Rev Saude Publica. 2017:51:119.

Copyright: This is an open-access article distributed under the terms of the Creative Commons Attribution License, which permits unrestricted use, distribution, and reproduction in any medium, provided that the original author and source are credited. 


\section{INTRODUCTION}

Healthcare-associated infections (HAI) are a public health concern worldwide. According to the World Health Organization (WHO), nations should have HAI Programs (HAIP) at national and local (healthcare settings) levels ${ }^{32}$. A national program is intended to regulate, provide guidance, promote, and supervise compliance with regulations ${ }^{32}$. The HAIP at local level aim to prevent the occurrence of HAI in patients, healthcare workers, and visitors. Well established HAIP are required to deal with outbreaks.

The HAIP vary among countries, resulting in differences in outcomes of HAI rates. Therefore, there is scope for considerable cross-national learning. Studying the processes by which HAIP have been developed in different countries over time will help us to understand the trajectory of change and to identify areas for improvement.

The objective of this study was to identify the main drivers and events underlying the development of public policies on HAI prevention and control (P\&C) in two countries and draw out policy lessons from historical experience. Brazil and the United Kingdom (UK) were selected as both have healthcare systems informed by the Beveridge model, involving government funding of healthcare services, financed by general taxation ${ }^{15,27}$.

We conducted a historical overview of national HAIP, by an open-ended review of published sources describing key policy developments. From this literature, we identified four sequential phases for the development of HAI P\&C policies at national level. Formation (development of infection prevention techniques and practices); Consolidation (acknowledgement of HAI as a public health problem and development of the initial proposals of national HAIP); Standardization (consolidation of HAIP and establishment of nation-wide regulations); Monitoring and Evaluation (full establishment of HAIP at national level including mechanisms for measurement; recognition of HAI as a relevant patient safety issue, focus on continuous quality improvement and cost savings). As presented below (summarized on Figure), elements of each of these four phases were seen in both countries, albeit in different periods.

\section{United Kingdom}

Formation. In the early of the 20th century, the UK saw significant scientific discoveries on $\mathrm{P} \& \mathrm{C}$, despite considerable regional variations in healthcare practices. The inauguration of the National Health Service (NHS) in $1948^{31}$ saw the beginning of national initiatives to reduce HAI, and epidemics of Staphylococcus aureus during the 1950s brought these issues to wider public attention.

Consolidation. During the 1960s, the P\&C of HAI was placed as an essential component for healthcare practices. This included the formal establishment of infection control as a nursing specialty, as well as the inauguration of working groups, conferences, and journals. These activities helped to raise the concern about HAI at the national and politics level.

Standardization. Changes to national policy related to healthcare organizations settled legal responsibility of individual providers for effective HAIP. In addition, publications of detailed national guidelines, and reporting mechanisms as scientific and professional communities increasingly gained a place in policy level decision making, such as through the National Institute of Clinical Excellence. Together, these developments raised HAIP compliance.

Monitoring and Evaluation. Currently, HAIP are well embedded into national healthcare activities and organizations; guidance on P\&C and surveillance systems are under the Public Health England authority. Each country within the UK has its own HAIP led by national public health bodies based on similar principles and practices. Practice is shaped by national evidence-based guidelines ${ }^{16}$ and broad principles of best practice with the aim of integration into routine practice. A national surveillance program for HAI covers Staphylococcus aureus, Escherichia coli, Clostridium difficile, surgical site infections, and patients with urinary catheter, producing annual reports. In 2015, there was an increased policy focus on antibiotic resistance 
Beginning of

hospital infection

control committees
Infection control

moved to the

forefront of the

healthcare agenda

Integration of

infection control

within the clinical professions $^{\dagger}$

\section{Increased \\ regulation on \\ infection control \\ Increasing \\ number of \\ epidemiological \\ studies on $\mathrm{HAl}^{\mathrm{h}}$ \\ Establishment of \\ formal structures to \\ manage infection \\ control at state and \\ federal levels Early \\ stages of monitoring \\ of $\mathrm{HAl}$ at}

national leveli

\begin{tabular}{lllll}
\hline Pre 1950s & 1950s & 1960s & Somation & Consolidation
\end{tabular}

a In line with this awareness, training materials on surgical infection were created. Examples include the films: "Aseptic operating theatre technique" (1933), "Modern aseptic operating technique"17 (1933) and "The medical application of sulphonamides"29 (1948).

${ }^{b}$ As the result of the 1959 pandemic of Staphylococcus aureus infections, in April 1959 the first infection control nurse (ICN) was appointed at Torbay hospital, district of Exeter ${ }^{23}$.

c The first Infection Control Committee was established in the State of Rio Grande do Sul (Hospital Ernesto Dornelles) in $1963{ }^{1}$.

${ }^{\mathrm{d}}$ As part of this movement, in 1966,17 infection control nurses participated in the first infection control conference at Lyngford House in Taunton, Somerset (UK) ${ }^{14}$.

e In 1970, the Infection Control Nurses Association (ICNA) is formed ${ }^{14}$. By 1979, 64\% of health districts had appointed an ICN ${ }^{23}$. During the 1970s, several peer reviewed journal articles on infection control were published. Examples include: Bagshawe et al. ${ }^{5}$, Heddell and Mitchell ${ }^{12}$, and Barr and Hogg ${ }^{6}$.

${ }^{\mathrm{f}}$ The death of President Tancredo Neves in 1985 allegedly by HAI raised the awareness of HAI. Advances in the field included the establishment of the first association of specialists in infection control in 1987, the creation of a National Training Program on Healthcare Associated Infection (HAI) from Ministry of Health in 1987, and the beginning of the enactment of regulations on infection control at hospitals (e.g., Portaria 196/MS of 24th June 1983 and Portaria 15, of 23rd August 1988)

g Examples of documents supporting this movement include: the 'Griffiths Report' published in 1983, which defined general managers in NHS organizations (NHS Trusts) with ultimate responsibility for performance and quality; and 'The Cooke Report' published in 1988 by the Department of Health and Social Security, working with the Public Health Laboratory Service, which included guidance on hospital infection control.

h Regulations on infection control included: (i) the Ordinance 930/92 (1992) from Ministry of Health, which included normatives for infection control at hospitals, (ii) the Law 9,431 of 6th January 1997, which introduced the compulsory requirement of an Infection Control Program and Infection Control Committee at hospitals, and (iii) the Law 2,616 of 12th May 1998, which established minimum infection control measures for Hospital's Infection Control Units. In 1995, the first national large prevalence study was conducted, including 99 hospitals. In 1999, the National Sanitary Agency (ANVISA) was established with regulatory powers on HCAI.

' Examples of standards included: (i) Infection Control Standards Working Party (1993), Standards in infection control in hospitals. Public Health Laboratory Service: London; and (ii) Department of Health (1995), Hospital Infection Control: Guidance on the Control of Infection in Hospitals. London: Department of Health. In 1999, the National Institute for Clinical Excellence (NICE) was stablished. NICE issues clinical guidelines, patient pathways, cost effectiveness, and research evidence synthesis, including on $\mathrm{HAl}$.

i Examples of this trend included: (i) the creation of UCISA (Hospital Infection Control Unit), designated to deal with the National HAI Prevention \& Control Program (2000); (ii) the first governmental surveillance system for HCAI in the State São Paulo (2004); (iii) the beginning of the National Governmental Surveillance System (ANVISA) (2011); and (iv) the creation of the National Infection Prevention and Control Committee with expert to support the National HCAI Prevention and Control Program (2012).

${ }^{k}$ In 2001, the Health Protection Agency (HPA) was established to monitor patient safety incidents, oversaw safety aspects of hospital design, cleanliness and food. In 2001, the National Patient Safety Agency (NPSA) was created as a Special Health Authority to monitor patient safety incidents including HCAI incidents. In 2004, the Healthcare Commission (HC) began assessing organisations on their policies and procedures for prevention and control of HCAl. In 2009, the Care Quality Commission (CQC) took over from HC and continued a programme of inspections with additional powers relating to cleanliness and infections.

Figure. Evolution of healthcare-associated infection (HAI) prevention and control in the United Kingdom and Brazil until 2015.

and antibiotics over prescription following reports of continued overuse ${ }^{24}$. This also includes providing operational guidance for health teams regarding the prevention and management of HAI for all healthcare settings including the National Health Service and the private sector. As a result, a downward trend in HAI rates ${ }^{13}$ is reported, from point prevalence surveys.

\section{Brazil}

Formation. The start of HAIP in Brazil dated of the 1960s, with the formal creation of the first Infection Control Committee (ICC) in the state of Rio Grande do Sul ${ }^{1}$. By the end of the political military regime, the fact that the first civil president in 1985 supposedly died due to HAI fostered a visibility of the role of ICC. At the time, HAI P\&C initiatives were led by 
a National Training Program on $\mathrm{HCAl}$ - The Brazilian Ministry of Health $(\mathrm{MoH})$ used the strategy of "training the trainers". Initially, a centralized training program occurred in Brasilia, Federal District. After that, the training program was carried out at national level using voluntary training centers and their staff. All didactic material was provided by the $\mathrm{MoH}$.

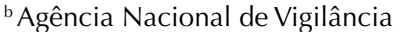
Sanitária. Relatório descritivo de investigação de casos de infecções por micobactérias não tuberculosas de crescimento rápido (MCR) no Brasil no período de 1998 a 2009. Brasília (DF): ANVISA; 2011 [cited 2011 Nov 25]. Available from: http:// www.anvisa.gov.br/hotsite/ hotsite_micobacteria/relatorio_ descrito_mcr_16_02_11.pdf

c Agência Nacional de Vigilância Sanitária. Segurança do paciente. Brasília (DF): ANVISA; s.d. [cited 2015 May 30]. Available from: https://www20.anvisa.gov.br/ segurancadopaciente/

dMinistério da Saúde (BR), DATASUS. Formsus: versão 3.0: Notificação de agregado de casos e surto em serviços de saúde. Brasília (DF): DATASUS; s.d. [cited 2015 May 30]. Available from: http://formsus. datasus.gov.br/site/formulario. php?id_aplicacao=8934

e Agência Nacional de Vigilância Sanitária. Segurança do paciente: PNPCIRAS 2016-2020 Brasília (DF): ANVISA; s.d. [cited 2015 May 30]. Availale from: https://www20.anvisa. gov.br/segurancadopaciente/ index.php/publicacoes/item/ pnpciras-2016-2020

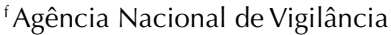
Sanitária. Segurança do paciente. Brasília (DF): ANVISA; s.d. [cited 2015 May 30]. Available from: https://www20.anvisa.gov.br/ segurancadopaciente/ individual professional associations. In 1987, the São Paulo Association of Infection Control and Epidemiology (APECIH - Associação Paulista de Epidemiologia e Controle de Infecção Relacionada à Assistência à Saúde) was founded, offering a central point of focus for the $\mathrm{P} \& \mathrm{C}$ of HAI, disseminating scientific knowledge and bringing together professional activities in the area. In the same year, the National Association of Professionals (ABIH - Associação Brasileira dos Profissionais em Controle de Infecção e Epidemiologia Hospitalar) was created and subsequently, the Ministry of Health began a national training program ${ }^{\mathrm{a}}$.

Consolidation. In the decade of 1980s, the creation of the Unified Health System(SUS) established health as a right in the country ${ }^{9}$. Subsequently, the 1990s saw increasing consolidation of HAI $\mathrm{P} \& \mathrm{C}$ at the policy level. National regulations were reviewed, culminating in a law making it compulsory for all hospitals to establish an ICC. The first national HAI prevalence study was carried out in the 1990s, although a follow-up study was not conducted for nearly 20 years ${ }^{21,26}$.

Standardization. Standardization in Brazil can be seen to gather pace following outbreaks of HAI in the late 1990s. This includes the 1996 outbreak of intoxication by cyanobacteria at a hemodialysis unit in Caruaru, Northeastern Brazil, due to the use of improperly treated water, leading to 126 HAI cases and 60 deaths $^{25}$. Further outbreaks of fast growing Mycobacteria ${ }^{\mathrm{b}}$ and multidrug resistant microorganisms have triggered the development of further regulations by the National Sanitary Agency (ANVISA) ${ }^{4,7,18,20,30}$. Standardization was strengthened by the 1998 Ministry of Health regulation defining the role of national, state, and municipal surveillance systems to monitor and evaluate P\&C of HAI nationwide (Figure).

Currently, the coordination of the national HAIP is carried out by ANVISA, which sets the basic elements for $\mathrm{P} \& \mathrm{C}$ of HAI, including written guidelines and a surveillance system. This system is targeted at catheter-related bloodstream infections at the intensive care units and high risk nurseries and surgical site infection ${ }^{c}$. A system for outbreak notification ${ }^{\mathrm{d}}$ is in place and the National HAIP is publicly available $\mathrm{e}^{\mathrm{e}}$

Since 2000, ANVISA established working groups involving experts to develop guidelines on $\mathrm{P} \& \mathrm{C}$ of HAI and also created the National Infection P\&C Committee to support the national HAIP. Recently, Brazil initiated a patient safety program at the national level ${ }^{19}$.

Data from the national surveillance system shows a huge variation in HAI rates among the states. There is also heterogeneity at the local level, with some hospitals having well established HAIP, while others have almost no initiatives in this area ${ }^{19,21}$.

\section{FINAL CONSIDERATIONS}

Across the two countries, we found similarities in the phases of HAI public policy, though, when compared to the UK, the start of each phase in Brazil took place around 20 years later. Of note, our analysis sought to identify trends in the HAIP at national level, rather than considering local practices, which are likely to vary greatly.

This article focuses on the development of HAI public policies in Brazil and in the UK. However, other factors may have influenced the attention surrounding HAI. From the start, in the past decades, there were significant differences in the economic, cultural, and political landscape of the two countries. Second, although both healthcare systems are informed by the Beveridge model, the way each system is organized may affect the perspectives of HAI prevention ${ }^{10}$. The NHS began in the UK in 1948, while in Brazil, the SUS was not fully developed until the 1990s. Whereas in the UK free and comprehensive healthcare provision dates from the late 1940s, in Brazil, health as a citizen's right and a duty of the state was only recognized with the promulgation of a new constitution in 1988. The principles of universality, comprehensiveness, and social participation adopted by the SUS did not exist before ${ }^{22}$. This perception of citizen's rights is probably associated with the raising of awareness of the importance of $\mathrm{P} \& \mathrm{C}$ of HAI. Hence, this can be a relevant driven force to promote $\mathrm{P} \& \mathrm{C}$ policies. Worldwide, healthcare systems are evolving and encompassing more complex and diverse 
environments of care (e.g. primary and secondary care, community care, etc.) $)^{10,15}$. Therefore, strategies to prevent HAI should also evolve in order to be able to deal with this diversity.

Findings also suggest that additional international trends shaped HAI public policy developments. Namely, the cultural and political affinities between the UK and the USA facilitated the sharing of evidence and practice between the two countries. For example, the US SENIC study $(1980)^{11}$ demonstrated that effective programs could reduce at least $30 \%$ of HAI and gained widespread policy attention in the UK. However, we saw the influence from international studies being exerted much later in Brazil.

Evidence suggests that Brazil only developed scientific critical mass on the issue of HAI in the 1990s. Since then, the exchange between Brazilian and international researchers in this field promoted knowledge transfer and discussions on the feasibility of translating to the Brazilian context techniques and systems applied elsewhere ${ }^{28}$. Alongside the development of HAI research in Brazil, scientists have been asked by ANVISA to contribute in the Standardization process. In Brazil, we now see a better synchronicity between the scientific understanding and the HAI public policy that has allowed the country to arrive at the stages of Consolidation and Standardization. Further, stemming from our historical comparative overview, we would suggest that Brazil is likely to enter into a phase of Monitoring and Evaluation, which is already established in the UK. The influence of international bodies such as the WHO may have played a role in advancing the HAI subject, particularly in developing countries.

Another important driver of the development of HAIP in both countries was the attention brought by the occurrence of relevant outbreaks. In the two countries outbreaks and subsequent media campaigns led to periods of increased public and political sensitivity to the issue. The raising of awareness of legal and civil rights for the provision of quality and safe healthcare appeared to be a key pressure point for the processes of Standardization.

Patient safety has been accepted as a worldwide problem to be tackled and HAI rates are recognized as a key indicator of quality of care. Safer care can be seen as a shared goal in high and middle-income countries, and our study recognizes points of common development in HAIP in the UK and Brazil. Nevertheless, there remain significant differences between the two countries. In comparative terms, Brazil has to overcome multiple political and economic challenges in order to advance universal healthcare provision ${ }^{8}$. Indeed, for many middle-income countries, basic access to healthcare continues to be a problem for some portions of the population, and wherever this is the case, the prevention of HAI may be seen as a secondary concern ${ }^{3}$. A good balance between healthcare access, economic sustainability, and patient safety is the challenge for healthcare systems worldwide.

The analysis of the UK experience highlights several potentially useful lessons for health systems that have not yet reached the Monitoring and Evaluation phase. Amongst them, the need to consider HAI as a public health problem, consistent dissemination of evidence based guidelines, integration of scientific updates in the clinical practice, setting up of guidance addressed to different types of healthcare settings, and monitoring of epidemiologically relevant pathogens. Finally, citizen's engagement in the HAI policy making is highly desirable.

\section{REFERENCES}

1. Agência Nacional de Vigilância Sanitária. Breve histórico do controle de infecção no país. Brasília (DF); 2005 [cited 2016 Nov 2]. Available from: http://www.anvisa.gov.br/divulga/noticias/2005/130505_4.htm

2. Aseptic operating theatre technique. London: British Medical Association Welcome Trust; 1933 [cited 2016 Nov 2]. Available from: https://archive.org/details/Asepticoperatingtheatretechnique-wellcome

3. Allegranzi B, Bagheri Nejad S, Combescure C, Graafmans W, Attar H, Donaldson $\mathrm{L}$, et al. Burden of endemic health-care-associated infection in developing countries: systematic review and meta-analysis. Lancet. 2011;377(9761):228-41. https://doi.org/10.1016/S0140-6736(10)61458-4 
4. Andrade LN, Darini AL. Response to detection of New Delhi metallo-beta-lactamase-producing bacteria, Brazil. Emerg Infect Dis. 2015;21(6):1069-71. https://doi.org/10.3201/eid2106.140113

5. Bagshawe KD, Blowers R, Lidwell OM. Isolating patients in hospital to control infection: Part I-Sources and routes of infection. Br Med J. 1978;2(6137):609-613.

6. Barr JG, Hogg GM. Biotypes of Klebsiella pneumoniae (sensu lato) and Enterobacter aerogenes characterized by differential substrate metabolism: application of the technique. J Clin Pathol. 1979;32(9):935-43. https://doi.org/10.1136/jcp.32.9.935

7. Baruque Villar G, de Mello Freitas FT, Pais Ramos J, Dias Campos CE, de Souza Caldas PC, Santos Bordalo F, et al. Risk factors for Mycobacterium abscessus subsp. bolletii infection after laparoscopic surgery during an outbreak in Brazil. Infect Control Hosp Epidemiol. 2015;36(1):81-6. https://doi.org/10.1017/ice.2014.13

8. Doniec K, Dall'Alba R, King L. Austerity threatens universal health coverage in Brazil. Lancet. 2016;388(10047):867-8. https://doi.org/10.1016/S0140-6736(16)31428-3

9. Duncan P, Bertolozzi MR, Cowley S, Egry EY, Chiesa AM, França FOS. "Health for All" in England and Brazil? Int J Health Serv. 2015;45(3):545-63. https://doi.org/10.1177/0020731415584558

10. Goldrick BA. The practice of infection control and applied epidemiology: a historical perspective. Am J Infect Control. 2005;33(9):493-500. https://doi.org/10.1016/j.ajic.2005.04.250

11. Haley RW, Culver DH, Emori TG, Hooton TM, White JW. Progress report on the evaluation of the efficacy of infection surveillance and control programs. Am J Med. 1981;70(4):971-5. https://doi.org/10.1016/0002-9343(81)90563-5

12. Heddell GW, Mitchell AA. Evaluation and application of an improved bacteriocin typing method for Klebsiella aerogenes. J Clin Pathol. 1978;31(1):16-21. https://doi.org/10.1136/jcp.31.1.16

13. Hopkins S, Shaw K, Simpson L. English National Point Prevalence Survey on Healthcare Associated Infections and Antimicrobial Use, 2011: preliminary data. London: Health Protection Agency; 2012 [cited 2016 Mar 18]. Available from: http://webarchive.nationalarchives.gov. uk/20140714095446/http://www.hpa.org.uk/webc/HPAwebFile/HPAweb_C/1317134304594

14. Infection Prevention Society. A brief history in time. Seafield (UK): IPS; c2016 [cited 2016 Nov 2]. Available from: http://www.ips.uk.net/about/history/

15. Kulesher R, Forrestal E. International models of health systems financing. J Hosp Adm. 2014;3(4):127-39. https://doi.org/10.5430/jha.v3n4p12

16. Loveday HP, Wilson JA, Pratt RJ, Golsorkhi M, Tingle A, Bak A, et al. Epic3: national evidence-based guidelines for preventing healthcare-associated infections in NHS hospitals in England. J Hosp Infect. 2014;86 Suppl 1:S1-70. https://doi.org/10.1016/S0195-6701(13)60012-2

17. Modern aseptic operating technique. London: Wellcome Library at the Bow Hospital; 1933 [cited 2016 Nov 2]. Available from https://archive.org/details/Modernasepticoperatingtechnique-wellcome

18. Oliveira GA, Faria JB, Levy CE, Mamizuka EM. Characterization of the Brazilian endemic clone of methicillin-resistant Staphylococcus aureus (MRSA) from hospitals throughout Brazil. Braz J Infect Dis. 2001;5(4):163-70. https://doi.org/10.1590/S1413-86702001000400001

19. Oliveira HM, Silva CP, Lacerda RA. Policies for control and prevention of infections related to healthcare assistance in Brazil: a conceptual analysis. Rev ESC Enferm USP. 2016;50:505-11. https://doi.org/10.1590/S0080-623420160000400018

20. Padoveze MC, Fortaleza CMCB, Freire MP, Assis DB, Madalosso G, Pellini ACG, et al. Outbreak of surgical infection caused by non-tuberculous mycobacteria in breast implants in Brazil. J Hosp Infect. 2007;67(2):161-7. https://doi.org/10.1016/j.jhin.2007.07.007

21. Padoveze MC, Fortaleza CM, Kiffer C, Barth AL, Carneiro IC, Giamberardino HI, et al. Structure for prevention of health care-associated infections in Brazilian hospitals: a countrywide study. Am J Infect Control. 2016;44(1):74-9. https://doi.org/10.1016/j.ajic.2015.08.004

22. Paim J, Travassos C, Almeida C, Bahia L, Macinko J. The Brazilian health system: history, advances, and challenges. Lancet. 2011;377(9779):1778-97. https://doi.org/10.1016/S0140-6736(11)60054-8

23. Perry C. The infection control nurse in England: past, present and future. Br J Infection Control. 2005;6(5):18-21. https://doi.org/10.1177/14690446050060050601

24. Pinder R, Sallis A, Berry D, Chadborn T. Behaviour change and antibiotic prescribing in healthcare settings: literature review and behavioural analysis. London: Public Health England; 2015 [cited 2016 Mar 18]. Available from: https://www.gov.uk/government/uploads/system/uploads/ attachment_data/file/405031/Behaviour_Change_for_Antibiotic_Prescribing_-_FINAL.pdf 
25. Pouria S, Andrade A, Barbosa J, Cavalcanti RL, Barreto VTS, Ward CJ, et al. Fatal microcystin intoxication in haemodialysis unit in Caruaru, Brazil. Lancet. 1998;352(9121):21-6. https://doi.org/10.1016/S0140-6736(97)12285-1

26. Prade SS, Oliveira ST, Rodrigues R, Nunes FA, Netto EM, Félix JQ, et al. Estudo brasileiro da magnitude das infecções hospitalares em hospitais terciários. Rev Control Infec Hosp. 1995;2:11-24.

27. Reid TR. The healing of America: a global quest for better, cheaper, and fairer health care. New York: Penguin Books; 2010.

28. Starling CEF, Couto BRGM, Pinheiro SMC. Applying the Centers for Disease Control and Prevention and National Nosocomial Surveillance system methods in Brazilian hospitals. Am J Infect Control. 1997;25(4):303-11.

29. The medical application of sulphonamides. London: British Medical Association; 1948 [cited 2016 Nov 2]. Available from: https://archive.org/details/Medical_application_of_sulphonamides-wellcome

30. Viana-Niero C, Lima KVB, Lopes ML, Rabello MCS, Marsola LR, Brilhante VCR, et al. Molecular characterization of Mycobacterium massiliense and Mycobacterium bolletii in isolates collected from outbreaks of infections after laparoscopic surgeries and cosmetic procedures. I Clin Microbiol. 2008;46(3):850-5. https://doi.org/10.1128/JCM.02052-07

31. Webster C. The National Health Service: a political history. Oxford: Oxford University Press; 2002.

32. World Health Organization. Core components for infection prevention and control programmes: assessment tools for IPC programmes. Geneva: WHO; 2011 [cited 2015 May 30]. Available from: http://www.who.int/csr/resources/publications/HSE_GAR_BDP_2011_3/en

Funding: São Paulo Research Foundation and British Council Researcher Links Workshop 2014 (FAPESP Process 2014/50506-0)

Authors' Contributions: All authors contributed to design and planning of the study. MCP, CMCBF, VBP collected data about Brazil and SM and SB collected data about UK. All authors worked in the analysis and interpretation of the data, prepared, review and approved the final version of the manuscript and have public responsibility for the content of the article.

Conflict of Interest: The authors declare no conflict of interest. 